\title{
Assessment of Agriculture Drought in Uthangarai Taluk, Krishnagiri District Using Remote Sensing and GIS Techniques
}

\author{
Senthil Kumar .C ${ }^{1}$, Purushothaman .B .M² \\ ${ }^{1}$ P.G. Student, Department of Civil Engineering, Adhiyamaan College of Engineering, Hosur, India \\ ${ }^{2}$ Assistant Professor, Department of Civil Engineering, Adhiyamaan College of Engineering, Hosur, India
}

\begin{abstract}
Drought is a serious natural hazard with far-reaching impacts including soil damages, economic losses, and threatening the livelihood and health of local residents. To monitor the present (2015) vegetation health across Uthangarai taluk using Remote Sensing and Gis techniques. Landsat datasets with a spatial resolution of $30 \mathrm{~m}$ and from different platforms were used to identify the VCI (Vegetation Condition Index) and TCI (Temperature Condition Index). The VCI is based on the Normalized Difference Vegetation Index (NDVI) datasets. Land surface temperature (LST) datasets were used to extract Temperature condition index. As a result, the VHI (Vegetation Health Index) was produced and classified into five categories: extreme, severe, moderate, mild, and no drought. The results show practically extreme drought has mainly occurred in north and west region in Uthangarai taluk. It is observed that moderate to severe drought condition has occurred in singarapettai, samalpatti, karappattu, kallavi and anandur. Mild drought condition has occurred in Uthangarai, egur, viswasampatti and kilkuppam. This approach allows decision makers to monitor, investigate and resolve drought conditions more effectively.
\end{abstract}

Keywords: Drought, Remote Sensing, GIS, Vegetation Indices, NDVI, VCI, LST, TCI, VHI

\section{Introduction}

Drought is a worldwide phenomenon that threats the future of water and food supplies, as well as the global economy. Since 1900, more than eleven million people have died as a consequence of drought and more than two billion have been affected by drought, which is more than any other physical hazard. Drought is generally defined as an extended period a season, a year, or several years of deficient precipitation compared with the statistical multiyear average for a region that results in a water shortage for some activity, group or environmental sector. While research in the early 1980's uncovered more than 150 published definitions of drought, Wilhite \& Glantz (1985) classified drought into four types: meteorological, hydrological, agricultural, and socioeconomic. The first three approaches are more common and deal with ways to measure drought as a physical phenomenon. The last approach associates the supply and demand of some economic good with elements of meteorological, hydrological, and agricultural drought. Drought can be described by three characteristics (i.e., intensity, duration and spatial coverage), which can be assessed by the usage of drought indices. Drought indices are mainly special combinations of indicators, which are based primarily on meteorological and hydrological data. For example, the Palmer Drought Severity Index has been widely used by the U.S. Department of Agriculture to determine when to grant emergency drought assistance. The SPI (Standardized Precipitation Index) is an index based upon the probability of precipitation for any time scale. The CMI (Crop Moisture Index) reflects moisture supply in the short term across major crop-producing regions and is not intended to assess long-term droughts. The Vegetation Health index (VHI) is based on a combination of products extracted from vegetation signals, namely the Normalized Difference Vegetation Index (NDVI) and the Land Surface Temperature
(LST), both of which are initially derived from the NOAA Advanced Very High Resolution Radiometer (AVHRR) sensor. A complete analysis of drought indices is provided by Wilhite (2005). Satellite-based remote sensing has been widely used over the past decades, from a national to a global scale, to monitor many environmental activities, including drought. It provides continuous spatial and temporal measurements as well as a historical record of conditions across large geographic areas. Globally, drought monitoring has been studied extensively through different types of satellite sensors, such as MODIS, and AVHRR. Other studies in the region were based on AVHRR or MODIS with a coarse spatial resolution (i.e., $1 \mathrm{~km}$ and 250 $\mathrm{m}$, respectively). In this paper, vegetation area in Uthangarai Taluk, Krishnagiri District was examined during the year 1995 and 2015. NDVI and LST datasets were processed and interpreted across Uthangarai Taluk, Krishnagiri District using Landsat satellite images with a spatial resolution of 30 m. Combination of VCI and TCI images to get the Vegetation Health Index. Finally identifying Agriculture vulnerability zones in Uthangarai Taluk using Vegetation Health Index.

\section{Study Area}

The present study area is the Uthangarai Taluk in Krishnagiri District in the Tamil Nadu State of India. Total geographical area of the district is $528 \mathrm{Sq} . \mathrm{Kms}$. The district is situated in the Vellore District in North, Thiruvannamalai in East, Pochampalli taluk in West, Dharmapuri District in South. The Uthangarai Taluk lies between $12^{\circ} 11^{\prime} \mathrm{N}$ and $12^{\circ} 42^{\prime} \mathrm{N}$ latitudes and $78^{\circ} 51^{\prime} \mathrm{E}$ and $78^{\circ} 35^{\prime} \mathrm{E}$ longitudes. The study area is located $780 \mathrm{~m}$ above the Mean sea level. Geologically the area broadly consists of Charnockite, Granite, Mostly crystalline rocks and Gneisses rock. The important soil types encountered in the area can be broadly categorized into red, 


\section{International Journal of Science and Research (IJSR) \\ ISSN (Online): 2319-7064 \\ Index Copernicus Value (2013): 6.14 | Impact Factor (2015): 6.391}

loamy and clay soil. Climate condition is summer period of March, April, May, May and June reaching a maximum temperature of up to $40^{\circ} \mathrm{C}$. The temperatures drop in December and the low temperatures continue up to February, touching a minimum of $19^{\circ} \mathrm{C}$ in January. Uthangarai Taluk has an average annual rainfall of 750 to about $900 \mathrm{~mm}$.

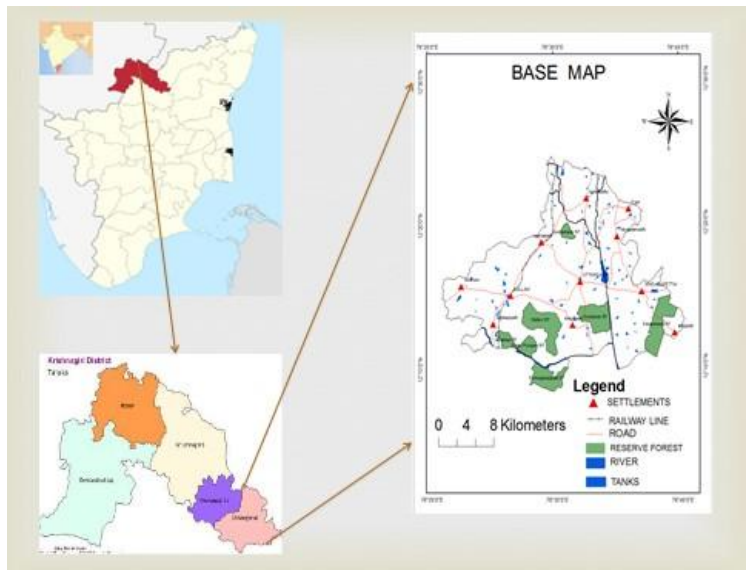

Figure 1: Study Area Map

\section{Materials and Methodology}

Survey of India maps 57H/10, 57H/11, 57L/14, 57L/15 on the scale of 1:50000 were acquired from Survey of India. Landsat TM \& ETM+ data of 1995 and 2015 were used for further analysis. Landsat satellite imagery was used to identify the VCI (Vegetation Condition Index) and TCI (Temperature Condition Index). The VCI was based on the Normalized Difference Vegetation Index (NDVI) datasets. Land surface temperature (LST) datasets were used to extract Temperature condition index. Combination of VCI and TCI identify the VHI (Vegetation Health Index) was produced. GIS tools were extensively used to identify the agriculture vulnerability areas.

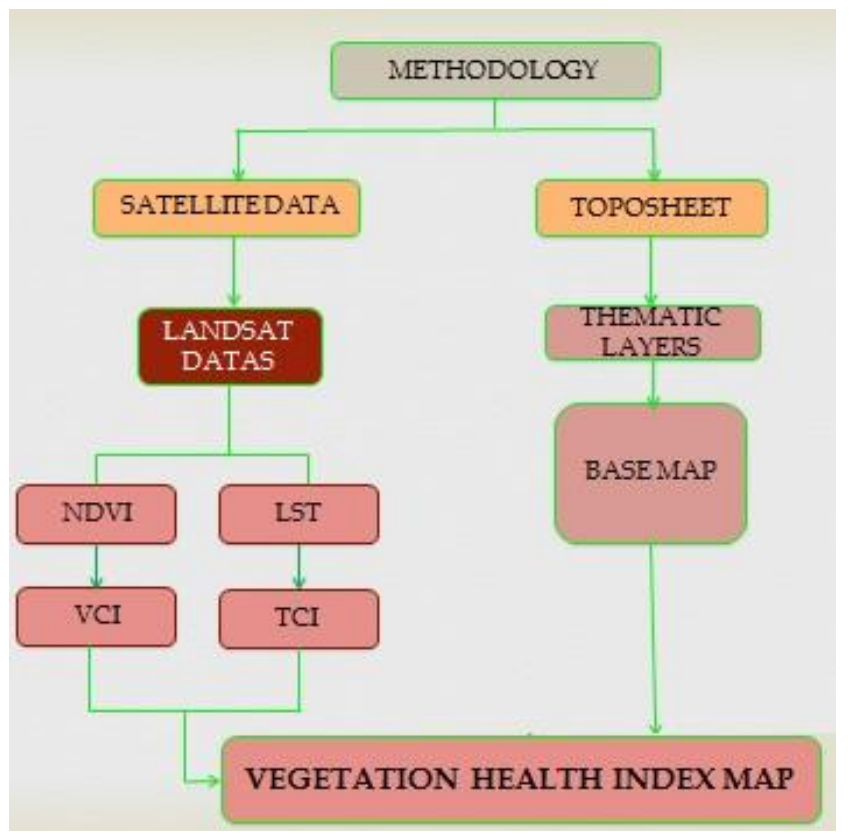

\section{Results and Discussion}

\section{Normalised Difference Vegetation Index}

he NDVI values are calculated for 1995and 2015 were represented in the figure $3 \mathrm{~A}$ and $3 \mathrm{~B}$ respectively. A minimum NDVI value of -0.4 and a maximum value of 0.668966 were observed in 1995 year data. The result of NDVI shows high vegetated area in northern part and less vegetated area in southern part. Similarly, a minimum NDVI value of -0.065911 and a maximum of 0.452611 were observed in 2015 year data. The NDVI results show high vegetated area in eastern part and less vegetated area in north western part.

\subsection{Land Surface Temperature}

The LST values are calculated for 1995and 2015 were represented in the figure $4 \mathrm{~A}$ and $4 \mathrm{~B}$ respectively. A minimum LST value is 27.19 and the maximum value shows 38.97 were observed in 1995 year data. The result of LST shows high temperature in karappattu, samalpatti and less temperature in anandur, kallavi, attipadi, egur, vellalapatti. Similarly, a minimum LST value is 24.78 and the maximum is 39.42 were observed in 2015. The result of LST shows high temperature in anandur, karappattu, samalpatti and less temperature in Uthangarai, egur, viswasampatti, kilkuppam.

\section{Vegetation Condition Index}

The VCI values are calculated for 1995and 2015 were represented in the figure $5 \mathrm{~A}$ and $5 \mathrm{~B}$ respectively. The Vegetation condition index of 1995 shows extreme drought in near kallavi and moderate to severe drought in anandur, karappattu, vellalapatti, egur, Uthangarai and no drought in kilkuppam, attipadi, singarapettai, viswasampatti, karappattu area. Similarly, The Vegetation condition index of 2015 shows extreme drought in near Uthangarai and moderate to severe drought in kallavi, samalpatti, Uthangarai, singarapettai, anandur, karappattu and mild drought in kilkuppam area.

\section{Temperature Condition Index}

The TCI values are calculated for 1995and 2015 were represented in the figure $6 \mathrm{~A}$ and $6 \mathrm{~B}$ respectively. The Temperature condition index result of 1995 shows extreme drought in samalpatti, near kallavi and moderate to severe drought in attipadi, karappattu, singarapettai and no drought in anandur, vellalapatti, Uthangarai, kilkuppam, kallavi, egur area. Similarly, The Temperature condition index result of 2015 shows extreme drought in near karappattu and moderate to severe drought in anandur, kallavi, samalpatti and no drought in Uthangarai, egur, viswasampatti, singarapettai, kilkuppam, vellalapatti area .

\section{Vegetation Health Index}

Kogan (2000) developed another index called as "Vegetation Health index" (VHI) from the joint information of VCI and TCI. The TCI teams up along with VCI to forms VHI as a substitute index characterizing vegetation health. The VHI is defined as:

VHI $=a^{*}$ VCI $+(1-a)$ TCI 


\section{International Journal of Science and Research (IJSR) \\ ISSN (Online): 2319-7064 \\ Index Copernicus Value (2013): 6.14 | Impact Factor (2015): 6.391}

where, , , $\mathrm{a}^{\text {ee }}$ is the coefficient determining the contribution of the two indices. The value for VHI less than 40 represents presence of vegetation stress and greater than 60 favors good condition for vegetation.

\begin{tabular}{|c|c|}
\hline Drought & Values \\
\hline Extreme & $<10$ \\
\hline Severe & $<20$ \\
\hline Moderate & $<30$ \\
\hline Mild & $<40$ \\
\hline No & $\geq 40$ \\
\hline
\end{tabular}

The VHI values are calculated for 1995 were represented in the figure 7A respectively. The Vegetation health index result of 1995 shows moderate drought in attipadi, karappattu, samalpatti and mild drought in anandur, vellalapatti, Uthangarai, kilkuppam, kallavi, egur, kilkuppam, singarapettai, viswasampatti area.

The VHI values are calculated for 2015 were represented in the figure 7B respectively. Similarly, The Vegetation health index result of 1995 shows extreme drought in near anandur and moderate to severe drought in kallavi, samalpatti, singarapettai, karappattu, vellalapatti, attipadi and mild drought in Uthangarai, egur, viswasampatti, kilkuppam area .
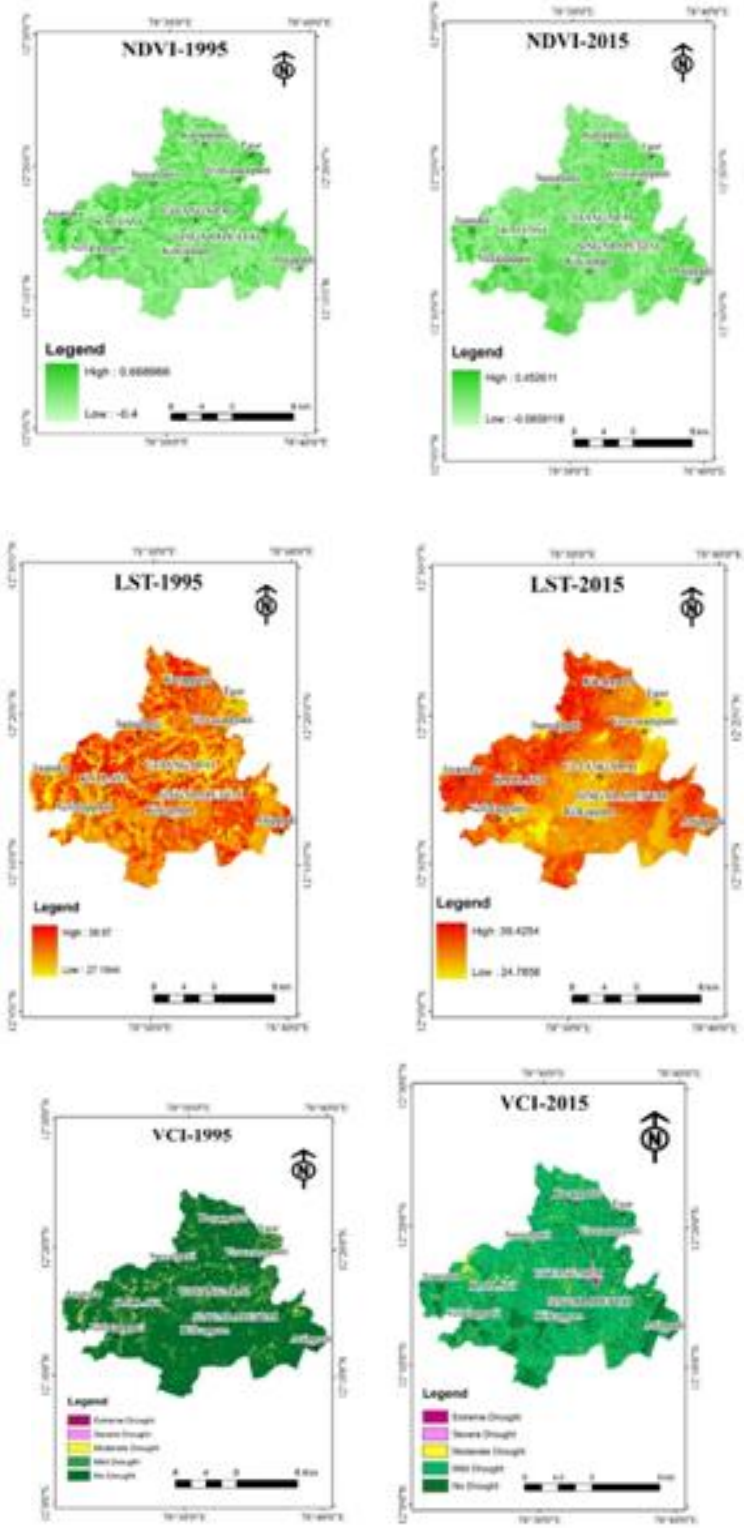

Paper ID: NOV162300
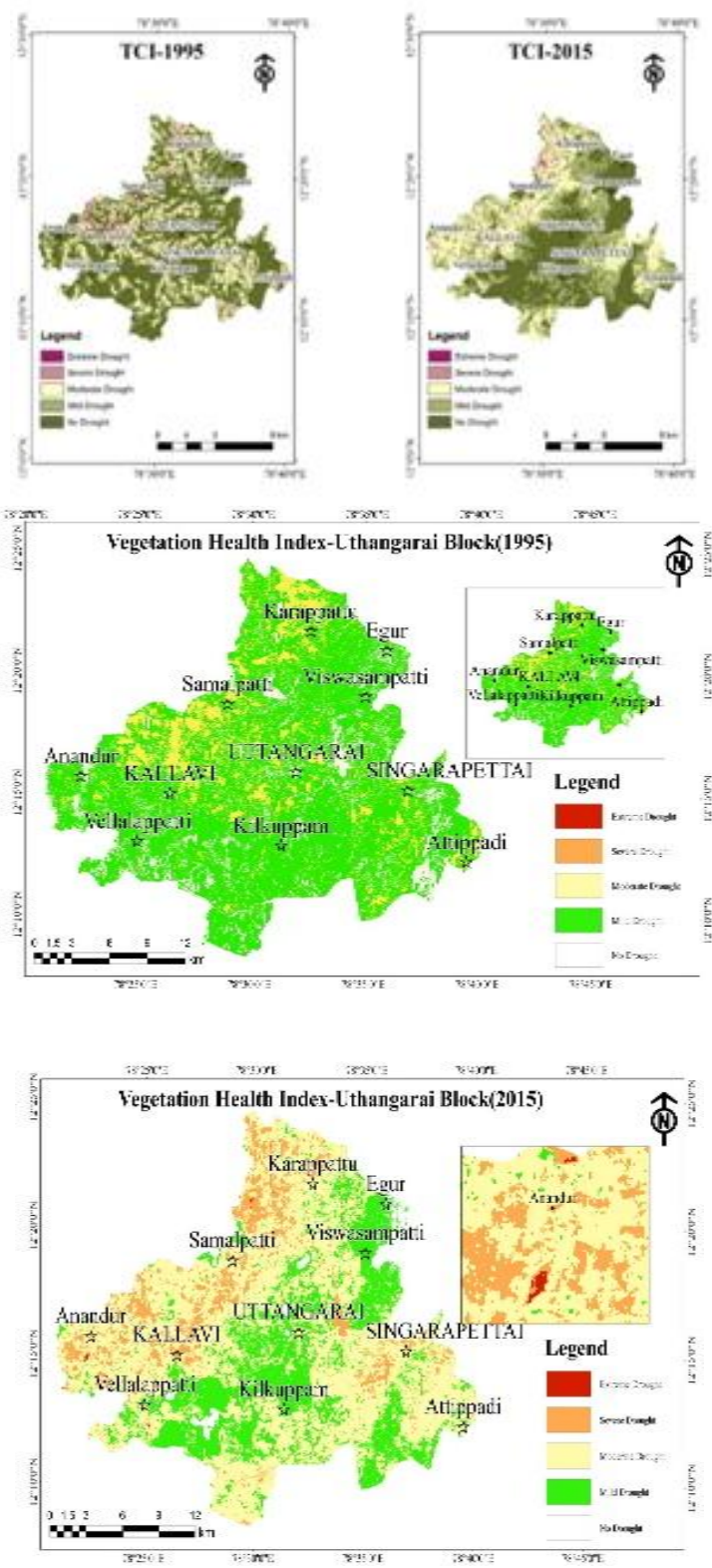

\section{Conclusion}

From the above study it is concluded that NDVI, LST, VCI, TCI and VHI are very useful for early detection of agricultural drought and hence should be a better methodology for remote sensing based drought assessment studies. In this paper the Vegetation Condition Index (VCI), resulting from the Normalized Difference Vegetation Index (NDVI), and the Temperature Condition Index (TCI), derived from Land Surface Temperature (LST), were combined to produce a Vegetation Health Index (VHI) map for 2015. The drought regions were highlighted and they cover the Anandur, Kallavi, Samalpatti, Karappattu and Singarapettai villages. From the study it is found that the villages are under threat and has to be prepared for mitigation to reduce the impacts of agricultural drought. This study concludes that real time satellite data can be well utilized for regional level agricultural vulnerability detection for early warning of agricultural drought. 


\section{References}

[1] D. Nithya and R. S. Suja Rose Assessing Agricultural Vulnerability Using Geomatic Technology: A Case Study of Srivilliputhur Taluk of Virudhunagar District, Tamil Nadu.(vol.2, no.2, 11-17)

[2] Krishna P.V., 1999, Vegetation Discrimination Using IRS-P3 WiFS Temporal Data Set - A Case Study from Rampa Forests, Eastern Ghats, A.P., Journal of Indian Society of Remote Sensing 27(3), pp. 149-153.

[3] Mokhtari, M.H., 2005, Agricultural drought Impact assessment using Remote Sensing: A case study Borkhar district Iran, M.Sc. thesis, International Institute for Geo-Information Science and Earth Observation Enschede, The Netherlands.

[4] Wilhelmi, V.O. and Wilhite, D.A., 2002, Assessing Vulnerability to Agricultural Drought: A Nebraska Case Study, Natural Hazards, Vol. 25: pp. 37-58

[5] Sumanta D., Malini R. C. \& Sachikanta N., 2013, Geospatial Assessment of Agricultural Drought (A Case Study Of Bankura District, West Bengal), International Journal of Agricultural Science and Research (IJASR),

[6] Chakraborty, A. and Sehgal, V.K., 2010, Assessment of Agricultural Drought Using MODIS Derived Normalized Difference Water Index, Journal of Agricultural Physics Division of Agricultural Physics, Indian Agricultural Research Institute, New Delhi - 110 012, Vol. 10, pp. 28-36.

[7] Riebsame, W. E., Changnon, S. A. Jr., and Karl, T. A., 1991, Drought and Natural Resources Management in the United States. Impacts and Implications of the 1987-1989 Drought, A Journal of Natural and Social Sciences, Paper 119.

[8] Seiler (1998), AVHRR-based vegetation and temperature condition indices for drought detection in Argentina. Advanced Space Research 21, 481484.

[9] Ramesh (2003) carried out a study on monitoring drought over India by studying VCI and TCI of NOAA AVHRR data. International Journal of Remote sensing, 24:4393-4402.

[10] Saha (2015) Assessment of agricultural drought in Rajasthan (India) using remote sensing derived Vegetation Condition Index (VCI) and Standardized Precipitation Index (SPI). The Egyptian Journal of Remote Sensing and Space Sciences (2015) 18, 53-63.

[11] Faour Ghaleb, Mhawej Mario and Najem Sandra, Regional Landsat-Based Drought Monitoring from 1982 to 2014. ISSN 2225-1154, 563-577; doi:10.3390/cli3030563 